\title{
The role of galectin-3 and its genetic variants in tumor risk and survival of patients with surgically resected early-stage non-small cell lung cancer
}

\author{
Cerrahi rezeksiyon uygulanmış erken evre küçük hücreli dlşı akciğer kanserli hastalarda galektin-3 ve \\ genetik varyantlarının tümör riski ve sağkalım üzerindeki rolü
}

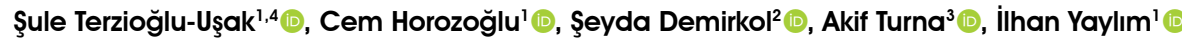 \\ Institution where the research was done: \\ Istanbul University Faculty of Medicine, Istanbul, Turkey
}

Author Affiliations:

\begin{abstract}
'Department of Molecular Medicine, Aziz Sancar Istanbul University Experimental Medicine Research Institute, Istanbul, Turkey 2Department of Molecular Biology and Genetics, Biruni University Faculty of Engineering and Natural Sciences, Istanbul, Turkey ${ }^{3}$ Department of Thoracic Surgery, Istanbul University-Cerrahpaşa, Cerrahpaşa Medical School, Istanbul, Turkey ${ }^{4}$ Department of Medical Biology, Faculty of Medicine, Bezmialem Vakıf University, istanbul, Turkey
\end{abstract}

\begin{abstract}
Background: The aim of this study was to investigate the possible relationship between galectin-3 gene variants, serum level, gene expression level, and the risks and survivals of resectable non-small cell lung cancer patients.

Methods: The rs4644 and rs4652 variants of galectin-3 were genotyped by TaqMan single nucleotide polymorphism assay using genomic deoxyribonucleic acid isolated from the peripheral blood of 65 (54 males, 11 females; mean age: $60.1 \pm 11.9$ years; range, 34 to 83 years) with Stage IA-IIIA non-small cell lung cancer who underwent primary surgical treatment and 95 healthy individuals ( 48 males, 47 females; mean age: $53.9 \pm 13.5$ years; range, 32 to 87 years) between March 2017 and September 2018. Circulating galectin-3 levels in serum samples of the patient and control groups were assessed by enzyme-linked immunosorbent assay. Messenger ribonucleic acid expression of galectin-3 in tumor and surrounding tissues of the patient group was examined by real-time quantitative polymerase chain reaction. Both predictive and prognostic significance of the results were analyzed.
\end{abstract}

Results: The presence of angiolymphatic invasion was significant in the patients with rs 4652 AA genotype $(\mathrm{p}=0.04)$. Serum galectin-3 levels were significantly higher in the patients than the controls $(\mathrm{p}<0.0001)$. The patients with $\mathrm{rs} 4644$ CA/CC $(p<0.0001$ and $p<0.0001)$ and $\mathrm{rs} 4652 \mathrm{AA} / \mathrm{AC}(\mathrm{p}=0.001$ and $\mathrm{p}<0.0001)$ genotypes had higher serum galectin-3 levels than their corresponding controls. Serum galectin- 3 levels increased in the presence of vascular invasion in patients with both rs $4644 \mathrm{AC}(\mathrm{p}=0.03)$ and $\mathrm{rs} 4652 \mathrm{AC}(\mathrm{p}=0.019)$ genotypes. The receiver operating characteristic curve suggested serum galectin-3 level as a strong predictive marker for the patient group with a cut-off value of $17.089 \mathrm{ng} / \mathrm{mL}$ (area under the curve: $0.910 \pm 0.04 ; 95 \%$ confidence interval: $0.832-0.988 ; \mathrm{p}<0.001$ ). Univariate analysis revealed the association of lower serum galectin-3 levels with better survival $(\mathrm{p}=0.048)$. Multivariate survival analysis showed that only high serum galectin-3 levels tended to be related to survival of the patients (hazard ratio: 5.106 ; $95 \%$ confidence interval: $0.956-27.267 ; \mathrm{p}=0.056$ ).

Conclusion: The presence of galectin-3 gene variants may lead to histopathological differences among patients with non-small cell lung cancer. Serum galectin-3 leve may be a valuable diagnostic biomarker and be associated with survival of these patients.

Keywords: Enzyme-linked immunosorbent assay, galectin-3, gene expression, non-small cell lung cancer, single nucleotide polymorphism genotyping.
$\ddot{O} Z$

Amaç: Bu çalışmada galektin-3 gen varyantları, serum düzeyi, gen ekspresyon düzeyi ile rezektabl küçük hücreli dışı akciğer kanseri hastalarının riskleri ve sağkalımları arasındaki olası ilişki araştırıldı.

Çalışma planı: Mart 2017 - Eylül 2018 tarihleri arasında galektin-3'ün rs4644 ve rs4652 varyantları, primer cerrahi tedavi yapılan küçük hücreli dışı akciğer kanserli 65 hastanın (54 erkek, 11 kadın; ort. yaş: 60.1 111.9 yıl; dağ $1 l_{1 \mathrm{~m}}, 34-83$ yıl) ve 95 sağlıklı bireyin (48 erkek, 47 kadın; ort. yaş: $53.9 \pm 13.5$ yıl; dağılım, 32-87 yıl) periferik kanından izole edilen genomik deoksiribonükleik asitler kullanılarak TaqMan tek nükleotid polimorfizm testi ile genotiplendi. Hasta ve kontrol gruplarının serum örneklerinde dolaşımdaki galektin-3 düzeyi, enzim bağlı immünosorbent testi ile değerlendirildi. Hasta grubunda tümör ve çevre dokulardaki galektin-3'ün haberci ribonükleik asit ekspresyonu, gerçek zamanlı kantitatif polimeraz zincir reaksiyonu ile incelendi. Bu sonuçların hem prediktif, hem de prognostik önemi analiz edildi.

Bulgular: Rs4652 AA genotipi olan hastalarda anjiyolenfatik invazyon varlığ anlamlı idi $(\mathrm{p}=0.04)$. Kontrol grubuna kiyasla, hastalarda serum galektin-3 düzeyleri anlamlı düzeyde yüksekti $(\mathrm{p}<0.0001)$. Rs4644 CA/CC $(\mathrm{p}<0.0001$ ve $\mathrm{p}<0.0001)$ ve $\mathrm{rs} 4652 \mathrm{AA} / \mathrm{AC}(\mathrm{p}=0.001$ ve $\mathrm{p}<0.0001)$ genotipleri olan hastalarda, karşılık gelen kontrollere kıyasla, serum galektin-3 düzeyleri daha yüksekti. Hem rs4644 ( $\mathrm{p}=0.03)$ hem de $\mathrm{rs} 4652(\mathrm{p}=0.019)$ AC genotipleri olan hastalarda, vasküler invazyon varlığında daha yüksek serum galektin-3 düzeyleri izlendi. Alıcı işletim karakteristik eğrisi, $17.089 \mathrm{ng} / \mathrm{mL}$ (eğri altında kalan alan: $0.910 \pm 0.04 ; \% 95$ güven aralığı: 0.832-0.988; $\mathrm{p}<0.001)$ kesme değeri ile serum galektin-3 düzeyinin hasta grubu için güçlü bir prediktif belirteç olduğunu gösterdi. Tek değişkenli analiz, daha düşük serum galektin-3 düzeylerinin daha iyi sağkalım ile ilişkili olduğunu ortaya koydu ( $\mathrm{p}=0.048)$. Cok değiskenli sağkalım analizi, yalnızca yüksek serum galektin-3 düzeylerinin hastaların sağkalımı ile ilişkili olma eğiliminde olduğunu gösterdi (risk oranı: 5.106; \%95 güven aralığı: 0.956-27.267; p=0.056).

Sonuç: Küçük hücreli dışı akciğer kanserli hastalarda galektin-3'ün genetik varyantlarının varlığı histopatolojik farklılıklara yol açabilir. Serum galektin-3 düzeyi, bu hastalar için değerli bir tanısal biyobelirteç olabilir ve sağkalım süreleri ile ilişkili olabilir.

Anahtar sözcükler: Enzim bağlı immünosorbent testi, galektin-3, gen ekspresyonu, küçük hücreli dışı akciğer kanseri, tek nükleotid polimorfizm genotiplemesi.

\section{Received: May 21, 2020 Accepted: September 16, 2020 Published online: April 26, 2021}

Correspondence: IIhan Yaylım, MD. İstanbul Üniversitesi Aziz Sancar Deneysel Tıp Araştırma Enstitüsü, Moleküler Tıp Anabilim Dalı, 34093 Fatih, istanbul, Türkiye. Tel: +90 212 - 4142020 e-mail: iyaylim@istanbul.edu.tr

\section{Cite this article as:}

Terzioğlu-Uşak Ş, Horozoğlu C, Demirkol Ș, Turna A, Yaylım I. The role of galectin-3 and its genetic variants in tumor risk and survival of patients with surgically resected early-stage non-small cell lung cancer. Turk Gogus Kalp Dama 2021;29(2):212-222 
Lung cancer is one of the most devastating diseases with an approximately $15 \%$ of cure rate globally. ${ }^{[1]}$ The two main types of lung cancer are common which are non-small cell lung cancer (NSCLC) and small cell lung cancer (SCLC)..$^{[2]}$ The former one accounts for the vast majority of lung cancer cases, of which almost two-thirds are detected at advanced stages. ${ }^{[3]}$ Surgery remains the primary option for curative therapy; however, most of patients die from poor diagnosis, as patients with the same pathological stage may have different genetic aberrations ${ }^{[4]}$ In addition, response against platinumbased chemotherapy as the standard first-line chemotherapy among patients of advanced NSCLC is quite different. ${ }^{[5]}$ Hence, it is particularly important to elucidate the underlying genetic differences and, thus, early detection and diagnosis would be enhanced for high-risk populations and patients with NSCLC.

Galectin-3 is an approximately $30 \mathrm{kDa}$ beta-galactoside-binding protein which is encoded by the LGALS3 gene located on chromosome $14 \mathrm{q} 21-\mathrm{q} 22$ in human and is composed of six exons and five introns. ${ }^{[6]}$ As a multifunctional protein, galectin-3 plays a pivotal role in cancer contributing to tumor progression, angiogenesis, and metastasis. ${ }^{[7-9]}$ Furthermore, alterations in expression and plasma levels of galectin-3 have been considered as potential biomarkers with a clinical value, particularly in cancer. ${ }^{[10,11]}$

There are two most common single nucleotide polymorphism (SNP) sites located in exon 3 of LGALS3, namely rs4644 and rs4652 variants. The variant of rs4644 +191 C>A substitutes histidine to proline at residue 64 , whereas the variant of rs4652 +292 A $>C$ changes threonine at residue 98 to proline. ${ }^{[12]}$ Double-sided roles of different variants of galectin-3 have been studied in different types of cancer. In a study, a polymorphism at rs4644 variant resulted in susceptibility to matrix metalloproteinase (MMP) cleavage and the acquisition of resistance to drug-induced apoptosis; thus, it was correlated with the incidence of breast cancer. ${ }^{[13]}$ In another study, a possible protective role of rs4644 variant of galectin-3 was suggested in prostate cancer. ${ }^{[14]}$ In addition, rs4652 variant, but not rs4644 variant, was associated with the tumor grade and prognosis of glioma in Chinese population. ${ }^{[15]}$ Besides, rs 4652 variant was thought to contribute to the susceptibility and chemotherapeutic drug resistance in gastric carcinoma. ${ }^{[16]}$ Recently, Fang et al. ${ }^{[17]}$ recorded that allele $\mathrm{C}$ of $\mathrm{rs} 4652$ variant might be risk factor for cervical cancer.
Despite the fact that SNPs play a key role in the occurrence and development of lung cancer, there has yet no a report showing specifically a correlation of galectin-3 gene variants with the risk and prognosis of NSCLC. In the present study, we, for the first time, aimed to investigate the association of galectin-3 and its genetic variants with the risk development and prognosis for NSCLC.

\section{PATIENTS AND METHODS}

\section{Study design and study population}

This retrospective study was conducted at Istanbul University-Cerrahpaşa, Cerrahpaşa Medical School, Department of Thoracic Surgery between March 2017 and September 2018. A total of 65 patients (54 males, 11 females; mean age: $60.1 \pm 11.9$ years; range, 34 to 83 years) with Stage IA-IIIA NSCLC who underwent primary surgical treatment and 95 healthy individuals (48 males, 47 females; mean age: $53.9 \pm 13.5$ years; range, 32 to 87 years) were included. The selection criteria for the control participants were negative family history of cancer and having no tumor. The participants were questioned in detail, if they had a genetic disorder or any other malignancies. None of the control individuals were diagnosed with any type of cancer and they were chosen to be numerically matched to case patients on the basis of age and sex. The NSCLC patients were followed up with telephone calling or nation-wide population registry system data. A written informed consent was obtained from each participant. The study protocol was approved by Clinical Research Ethics Committee of Bezmialem Vakif University (No: 71306642-050.01.04). The study was conducted in accordance with the principles of the Declaration of Helsinki. In the expression analysis, the control group referred to as tumor surrounding tissue which was distant from the tumor without any findings of the macroscopic invasion. The diagnosis of the NSCLC patients was confirmed by the pathological examinations of the resected tumor tissues according to the $7^{\text {th }}$ edition of the pathological Tumor, Node, Metastasis (TNM) staging system. ${ }^{[18]}$ Tumor tissue and tumor-free surrounding tissue samples from 18 NSCLC patients were collected for expression analysis.

\section{TaqMan SNP genotyping}

The peripheral blood samples from all participants were collected into the ethylenediaminetetraacetic acid (EDTA)-containing tubes. Genomic deoxyribonucleic acid (DNA) was isolated from peripheral circulating lymphocytes by salting-out process. ${ }^{[19]}$ The distribution of SNPs rs4644 and rs4652 were performed using the TaqMan SNP genotyping assays C___7593635_1_ and 
C___7593636_30, respectively. Briefly, approximately $50 \mathrm{ng}$ of each DNA sample was subjected to a 5 '-nuclease allelic discrimination assay using TaqMan Universal PCR Master Mix (Applied Biosystems Inc., CA, USA) and the primer-probe mix consisting of two SNP region-specific pre-validated primers, as well as mutation-specific fluorescence-labeled TaqMan minor groove binder (MGB) probes. In this study, one probe was labeled with VIC dye to detect the allele A; the second probe was labeled with fluorescein amidite dye to detect the allele $\mathrm{C}$. The reaction was amplified by an initial denaturation step of $2 \mathrm{~min}$ at $95^{\circ} \mathrm{C}$, followed by 40 cycles of $15 \mathrm{sec}$ at $95^{\circ} \mathrm{C}$ and $1 \mathrm{~min}$ at $60^{\circ} \mathrm{C}$. Endpoint analysis was performed on an ABI Prism 7900 Sequence Detection System (Applied Biosystems Inc., CA, USA).

\section{Enzyme-linked immunosorbent assay (ELISA)}

Blood serum was obtained from participants by centrifugation and stored $-80^{\circ} \mathrm{C}$. Serum levels of galectin-3 concentrations were measured in patients and controls by using human galectin-3 platinum ELISA kit (Invitrogen, Bender MedSystems, Vienna, Austria) (sensitivity: $0.29 \mathrm{ng} / \mathrm{mL}$; intraassay coefficient of variation [CV]: $7.5 \%$ and interassay CV: $5.4 \%$ ) according to the manufacturer's instructions.

\section{Real-time quantitative polymerase chain reaction (RT-qPCR)}

Total ribonucleic acid (RNA) was isolated from the tumor and non-malignant surrounding lung tissue specimens of the same patient by the TRizol (Invitrogen, CA, USA) method. Validation of RNA concentrations were performed by NanoDrop2000 (Thermo Fisher Scientific Inc., MA, USA). Firststrand complementary DNA (cDNA) was synthesized using high-capacity cDNA reverse transcription kit (Applied Biosystems Inc., CA, USA). The quantitative real-time PCR was conducted by Stratagene Mx3005P (Agilent Technologies Inc., CA, USA) system in the presence of SensiFAST TM SYBR ${ }^{\circledR}$ No-ROX green dye (Bioline Reagents Ldt., TN, USA). All PCR primers used were as follow: LGALS3 forward, 5'GTGCCTCGCATGCTGATAAC3' and reverse, 5'GCAACCTTGAAGTGGTCAGG3'; GAPDH primer, 5'TGCACCACCAACTGCTTAGC3' and reverse, 5'GGCATGGACTGTGGTCATGAG3'. Gene cards were analyzed using the threshold cycle $(\mathrm{CT})$ relative quantification method. The $\mathrm{CT}$ values were normalized for endogenous reference $[\triangle \mathrm{CT}=\mathrm{CT}(\mathrm{GAPDH})-\mathrm{CT}$ (LGALS3)] and compared with the control using the $\Delta \Delta \mathrm{CT}$ formula $[\Delta \Delta \mathrm{CT}=\Delta \mathrm{CT}$ (tumor tissue) $-\Delta \mathrm{CT}$ (surrounding healthy tissue as control)]. Relative messenger RNA (mRNA) expression (fold change) was calculated by $2-\Delta \Delta \mathrm{Ct}$ method (GAPDH for the internal control). Each sample was tested in duplicate.

\section{Statistical analysis}

Statistical analysis was performed using the PASW version 17.0 software (SPPS Inc., Chicago, IL, USA) and GraphPad Prism version 8.0.0 (GraphPad, La Jolla, CA, USA). The distribution of rs4644 and rs4652 genotypes and the frequency of alleles between the patients and control groups were compared using the chi-square, Fisher's exact, and Student's t-tests. Serum galectin-3 levels and galectin-3 mRNA expression analysis results between NSCLC patients and controls were analyzed using the Mann-Whitney $\mathrm{U}$ test. The inter-group differences of ELISA and pathological parameters with different genotypes were compared using the Kruskal-Wallis test. Multivariate logistic regression analysis was adjusted by risk factors in terms of galectin-3, sex, and smoking status. The receiver operating characteristic (ROC) curve analysis calculated the area under the curve (AUC) to check the diagnostic performance of serum galectin-3 level in NSCLC. The optimal cut-off value on ROC curve was determined with respect to AUC value by maximizing both specificity and sensitivity, as well as their summation. ${ }^{[20]}$ Prognostic factors were also evaluated in NSCLC patients. Differences in survival were investigated using the log-rank test in the univariate analysis, and multivariate analysis was done using the Cox proportional hazards regression model. A $p$ value of $<0.05$ was considered statistically significant.

\section{RESULTS}

Baseline characteristics of patients and healthy controls are summarized in Table 1. There were no significant differences in the mean age at the time of diagnosis between the groups $(\mathrm{p}=0.146)$. The incidence rate was higher in men (83.1\%) than in women (16.9\%) $(\mathrm{p}<0.001)$. The rate of smokers was higher in both groups $(84.6 \%$ in patient group vs. $70.5 \%$ in the control group than non-smokers $(15.4 \%$ in the patient group vs. $29.5 \%$ in the control group) $(\mathrm{p}=0.04)$. The median follow-up was 26 (range, 12 to 48) months. On the other hand, no significant differences in the distribution of genotypes and allele frequencies between the patients and controls were observed for both rs 4644 and rs 4652 variants (Table 2).

The clinical features of the patients with genotypes of rs4644 and rs4652 variants were presented in Table 3. Regarding disease's characteristics including tumor stage, lymph node metastasis, perineural invasion, 
Table 1. Baseline characteristics of study population

\begin{tabular}{|c|c|c|c|c|c|c|c|}
\hline \multirow[b]{2}{*}{ Characteristics } & \multicolumn{3}{|c|}{ Control group $(n=95)$} & \multicolumn{3}{|c|}{ Patient group $(n=65)$} & \multirow[b]{2}{*}{$p$} \\
\hline & $\mathrm{n}$ & $\%$ & Mean \pm SD & $\mathrm{n}$ & $\%$ & Mean \pm SD & \\
\hline Age (year) & & & $53.9 \pm 13.5$ & & & $60.14 \pm 11.9$ & 0.146 \\
\hline Sex & & & & & & & $<0.001$ \\
\hline Female & 47 & 49.5 & & 11 & 16.9 & & \\
\hline Male & 48 & 50.5 & & 54 & 83.1 & & \\
\hline Smoke & & & & & & & $0.04 *$ \\
\hline Yes & 67 & 70.5 & & 55 & 84.6 & & \\
\hline No & 28 & 29.5 & & 10 & 15.4 & & \\
\hline
\end{tabular}

SD: Standard deviation; * $\mathrm{p}<0.05$.

angiolymphatic invasion and vascular invasion, no association was observed among NSCLC patients with genotypes of rs4644 variant. However, there was a markedly suggestive evidence of the presence of angiolymphatic invasion for NSCLC patients who had AA genotype of rs4652 variant $(\mathrm{p}=0.04)$.

The mean serum galectin-3 levels were significantly higher in NSCLC patients $(26.05 \pm 1.77 \mathrm{ng} / \mathrm{mL})$, compared to healthy controls $(11.62 \pm 1.30 \mathrm{ng} / \mathrm{mL}) \quad(\mathrm{p}<0.0001) \quad$ (Figure 1a). The patients with CA and CC genotypes of rs4644 variant were associated a higher serum galectin-3 level compared to the controls (for CA genotype: $26.02 \pm 1.72$ vs. $12.08 \pm 2.05 \mathrm{ng} / \mathrm{mL}$, respectively; $\mathrm{p}<0.0001$; for $\mathrm{CC}$ genotype: $28.8 \pm 3.43 \mathrm{vs}$. $12.27 \pm 1.80 \mathrm{ng} / \mathrm{mL}$; respectively; $\mathrm{p}<0.0001$ )
(Figure 1b). Moreover, the patients with AC and AA genotypes of rs 4652 variant were correlated with higher serum galectin-3 levels, compared to controls (for AC genotype: $26.50 \pm 1.86 v s .12 .08 \pm 1.76 \mathrm{ng} / \mathrm{mL}$, respectively; $\mathrm{p}<0.0001$; for AA genotype: $28.76 \pm 3.43$ vs. $11.70 \pm 2.36 \mathrm{ng} / \mathrm{mL}$, respectively; $\mathrm{p}=0.001$ ) (Figure 1c). Moreover, serum galectin-3 levels of NSCLC patients with AC genotype of both rs4644 and rs4652 variants were found to be higher in the presence of vascular invasion than in the absence of it (for rs4644 variant: $30.81 \pm 2.04 \mathrm{ng} / \mathrm{mL} v s$. $23.03 \pm 1.85 \mathrm{ng} / \mathrm{mL}$, respectively; $\mathrm{p}=0.03$; for $\mathrm{rs} 4652$ variant: $31.94 \pm 2.20 \mathrm{ng} / \mathrm{mL}$ vs. $22.87 \pm 1.37 \mathrm{ng} / \mathrm{mL}$, respectively; $\mathrm{p}=0.019$, respectively) (Tables 4 and 5).

Multivariate logistic regression analysis was also tested for a statistical interaction in which the

Table 2. Genotype and allele frequencies for rs4644 and rs 4652 variants of galectin-3 in study population

\begin{tabular}{|c|c|c|c|c|c|}
\hline & \multicolumn{2}{|c|}{ Control group } & \multicolumn{2}{|c|}{ Patient group } & \multirow{3}{*}{$p$} \\
\hline & \multirow[t]{2}{*}{$\mathrm{n}$} & \multirow[t]{2}{*}{$\%$} & $\mathrm{n}$ & $\%$ & \\
\hline & & & \multicolumn{2}{|c|}{ rs4644 } & \\
\hline AA & 15 & 15.8 & 4 & 6.2 & \\
\hline $\mathrm{CA}$ & 32 & 33.7 & 30 & 46.2 & 0.099 \\
\hline $\mathrm{CC}$ & 48 & 50.5 & 31 & 47.7 & \\
\hline $\mathrm{C}$ allele & 128 & 67.4 & 92 & 70.8 & 0519 \\
\hline \multirow[t]{2}{*}{ A allele } & 62 & 32.6 & 38 & 29.23 & 0.519 \\
\hline & & & \multicolumn{2}{|c|}{ rs4652 } & \\
\hline AA & 37 & 38.9) & 27 & 41.5 & \\
\hline $\mathrm{AC}$ & 39 & 41.1 & 29 & 44.6 & 0.602 \\
\hline $\mathrm{CC}$ & 19 & 20 & 9 & 13.8 & \\
\hline A allele & 113 & 59.5 & 83 & 63.8 & 0430 \\
\hline $\mathrm{C}$ allele & 77 & 40.5 & 47 & 36.2 & 0.450 \\
\hline
\end{tabular}


Table 3. The genotype distribution for rs4644 and rs4652 variants of galectin-3 according to histopathological features of NSCLC patients

\begin{tabular}{|c|c|c|c|c|c|c|c|c|c|c|c|c|}
\hline \multirow[b]{3}{*}{ Features } & \multicolumn{6}{|c|}{ rs4644 } & \multicolumn{6}{|c|}{ rs4652 } \\
\hline & \multicolumn{2}{|c|}{ AA } & \multicolumn{2}{|c|}{$\mathrm{AC}$} & \multicolumn{2}{|c|}{$\mathrm{CC}$} & \multicolumn{2}{|c|}{ AA } & \multicolumn{2}{|c|}{$\mathrm{AC}$} & \multicolumn{2}{|c|}{$\mathrm{CC}$} \\
\hline & $\mathrm{n}$ & $\%$ & $\mathrm{n}$ & $\%$ & $\mathrm{n}$ & $\%$ & $\mathrm{n}$ & $\%$ & $\mathrm{n}$ & $\%$ & $\mathrm{n}$ & $\%$ \\
\hline \multicolumn{13}{|c|}{ Tumor stage } \\
\hline $\mathrm{T} 3+\mathrm{T} 4$ & 1 & 9.1 & 4 & 36.4 & 6 & 54.5 & 6 & 54,5 & 3 & 27.3 & 2 & 18.2 \\
\hline $\mathrm{T} 1+\mathrm{T} 2$ & 3 & 9.4 & 13 & 40.6 & 16 & 50 & 15 & 46,9 & 11 & 34.4 & 6 & 18.8 \\
\hline
\end{tabular}

Lymph node metastasis

$\begin{array}{lcccccccccccc}\text { N1, N2, N3 } & 0 & 0 & 5 & 35.7 & 9 & 64.3 & 9 & 64.3 & 4 & 28.6 & 1 & 7.1 \\ \text { N0 } & 4 & 13.8 & 12 & 41.4 & 13 & 44.8 & 12 & 41.4 & 10 & 34.5 & 7 & 24.1\end{array}$

Perineural invasion

$\begin{array}{lrrrrrrrrrrrr}\text { No } & 3 & 6.5 & 22 & 47.8 & 21 & 45.7 & 17 & 37 & 24 & 52.2 & 5 & 10.9 \\ \text { Yes } & 1 & 5.3 & 8 & 42.1 & 10 & 52.6 & 10 & 52.6 & 5 & 26.3 & 4 & 21.1\end{array}$

Angiolymphatic invasion

$\begin{array}{ccccccccccccc}\text { No } & 2 & 6.9 & 16 & 55.2 & 11 & 37.9 & * 8 & 27.6 & 18 & 62.1 & 3 & 10.3 \\ \text { Yes } & 2 & 5.6 & 14 & 38.9 & 20 & 55.6 & * 19 & 52.8 & 11 & 30.6 & 6 & 16.7\end{array}$

Vascular invasion

\begin{tabular}{ccccccccccccc} 
No & 2 & 4.3 & 23 & 50 & 21 & 45.7 & 18 & 39.1 & 23 & 50 & 5 & 10.9 \\
Yes & 2 & 10.5 & 7 & 36.8 & 10 & 52.6 & 9 & 47.4 & 6 & 31.6 & 4 & 21.1 \\
\hline
\end{tabular}

NSCLC: non-small cell lung cancer; ${ }^{*} \mathrm{p}<0.05$.
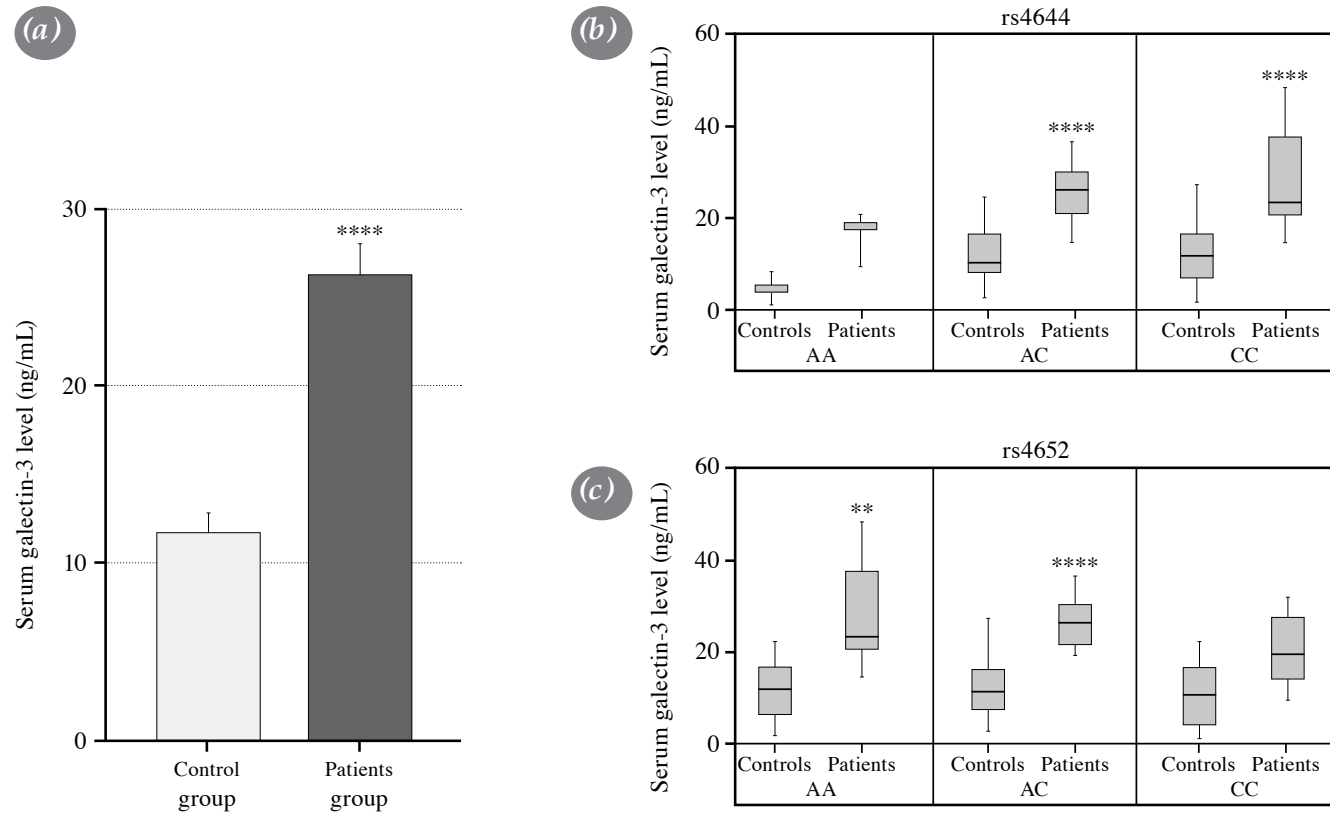

Figure 1. The comparison of serum galectin-3 levels (a) in controls vs. NSCLC patients (b) among NSCLC patients having genotypes of rs4644 variant (c) among NSCLC patients having genotypes of rs4652 variant. The data are given in mean \pm standard error.

NSCLC: Non-small cell lung cancer; ** $\mathrm{p}<0.01 ; * * * * \mathrm{p}<0.0001$ 
Table 4. Distribution of serum galectin-3 levels (ng/mL) according to histopathological features of NSCLC patients among genotypes of rs4644 variant

\begin{tabular}{|c|c|c|c|c|c|c|c|}
\hline \multirow[b]{2}{*}{ Features } & \multicolumn{2}{|c|}{ AA } & \multirow[b]{2}{*}{$p$} & \multirow{2}{*}{$\frac{\mathrm{AC}}{\mathrm{Mean} \pm \mathrm{SE}}$} & \multirow[b]{2}{*}{$p$} & \multirow{2}{*}{$\frac{\mathrm{CC}}{\mathrm{Mean} \pm \mathrm{SE}}$} & \multirow[b]{2}{*}{$p$} \\
\hline & Mean \pm SE & Mean & & & & & \\
\hline \multicolumn{8}{|c|}{ Tumor stage } \\
\hline $\mathrm{T} 3+\mathrm{T} 4$ & & \multirow[t]{2}{*}{9.72} & \multirow{2}{*}{0.667} & $27.6 \pm 2.7$ & \multirow{2}{*}{0.913} & $32.9 \pm 6.2$ & \multirow{2}{*}{0.315} \\
\hline $\mathrm{T} 1+\mathrm{T} 2$ & $19.4 \pm 1.2$ & & & $26.0 \pm 2.4$ & & $26.4 \pm 4.1$ & \\
\hline \multicolumn{8}{|c|}{ Node metastasis } \\
\hline Yes & & - & & $27.0 \pm 2.9$ & \multirow{2}{*}{1.00} & $33.9 \pm 5.8$ & \multirow{2}{*}{0.247} \\
\hline No & $16.2 \pm 3.3$ & & & $26.4 \pm 2.3$ & & $24.5 \pm 3.6$ & \\
\hline \multicolumn{8}{|c|}{ Perineural invasion } \\
\hline Yes & & 9.72 & \multirow{2}{*}{0.667} & $27.9 \pm 1.9$ & \multirow{2}{*}{0.445} & $29.6 \pm 5.0$ & \multirow{2}{*}{1.00} \\
\hline No & $19.4 \pm 1.2$ & & & $24.4 \pm 2.7$ & & $27.4 \pm 4.5$ & \\
\hline \multicolumn{8}{|c|}{ Vascular invasion } \\
\hline Yes & & 9.72 & \multirow{2}{*}{0.667} & $30.8 \pm 2.0$ & \multirow{2}{*}{$0.03 *$} & $24.5 \pm 3.6$ & \multirow{2}{*}{0.247} \\
\hline No & $19.4 \pm 1.2$ & & & $23.0 \pm 1.9$ & & $33.9 \pm 5.8$ & \\
\hline \multicolumn{8}{|c|}{ Angiolymphatic invasion } \\
\hline Yes & & 9.72 & \multirow{2}{*}{0.667} & $26.4 \pm 1.9$ & \multirow{2}{*}{0.641} & $28.76 \pm 3.43$ & \multirow{2}{*}{0.667} \\
\hline No & $19.4 \pm 1.2$ & & & $24.0 \pm 4.4$ & & - & \\
\hline
\end{tabular}

NSCLC: Non-small cell lung cancer; SE: Standard error; * $\mathrm{p}<0.05$.

Table 5. Distribution of serum galectin-3 levels $(\mathrm{ng} / \mathrm{mL})$ according to histopathological features of NSCLC patients among genotypes of rs4652 variant

\begin{tabular}{|c|c|c|c|c|c|c|c|}
\hline \multirow[b]{2}{*}{ Features } & \multirow{2}{*}{$\frac{\mathrm{AA}}{\mathrm{Mean} \pm \mathrm{SE}}$} & \multirow[b]{2}{*}{$p$} & \multirow{2}{*}{$\frac{\mathrm{AC}}{\mathrm{Mean} \pm \mathrm{SE}}$} & \multirow[b]{2}{*}{$p$} & \multicolumn{2}{|c|}{$\mathrm{CC}$} & \multirow[b]{2}{*}{$p$} \\
\hline & & & & & Mean \pm SE & Mean & \\
\hline \multicolumn{8}{|c|}{ Tumor stage } \\
\hline $\mathrm{T} 3+\mathrm{T} 4$ & $32.9 \pm 6.2$ & \multirow{2}{*}{0.315} & $28.1 \pm 3.8$ & \multirow{2}{*}{1.00} & $18.0 \pm 8.3$ & & \multirow{2}{*}{0.80} \\
\hline $\mathrm{T} 1+\mathrm{T} 2$ & $26.4 \pm 4.1$ & & $26.9 \pm 2.4$ & & $21.5 \pm 3.6$ & & \\
\hline \multicolumn{8}{|c|}{ Node metastasis } \\
\hline Yes & $33.9 \pm 5.8$ & \multirow{2}{*}{0.247} & $24.6 \pm 2.7$ & \multirow{2}{*}{0.50} & & \multirow[t]{2}{*}{31.72} & \\
\hline No & $24.5 \pm 3.6$ & & $28.0 \pm 2.3$ & & $18.02 \pm 2.75$ & & \\
\hline \multicolumn{8}{|c|}{ Perineural invasion } \\
\hline Yes & $29.6 \pm 5.0$ & \multirow{2}{*}{1.00} & $27.3 \pm 2.8$ & \multirow{2}{*}{0.914} & $22.6 \pm 6.6$ & & \multirow{2}{*}{0.70} \\
\hline No & $27.4 \pm 4.5$ & & $25.9 \pm 2.7$ & & $18.0 \pm 1.5$ & & \\
\hline \multicolumn{8}{|c|}{ Vascular invasion } \\
\hline Yes & $24.5 \pm 3.6$ & \multirow{2}{*}{0.247} & $31.9 \pm 2.2$ & \multirow{2}{*}{$0.019 *$} & $18.0 \pm 8.3$ & & \multirow{2}{*}{0.80} \\
\hline No & $33.9 \pm 5.8$ & & $22.9 \pm 1.4$ & & $21.5 \pm 3.6$ & & \\
\hline \multicolumn{8}{|c|}{ Angiolymphatic invasion } \\
\hline Yes & $28.8 \pm 3.4$ & & $27.1 \pm 2.2$ & \multirow{2}{*}{0.533} & $20.7 \pm 5.0$ & & \multirow{2}{*}{1.00} \\
\hline No & - & & $24.0 \pm 4.4$ & & $19.4 \pm 1.2$ & & \\
\hline
\end{tabular}

NSCLC: Non-small cell lung cancer; SE: Standard error; $* \mathrm{p}<0.05$. 
Table 6. Multivariate logistic regression analysis for the risk of development of NSCLC

\begin{tabular}{lccc}
\hline & \multicolumn{2}{c}{ Parameters (controls/patients) } & \\
\cline { 2 - 3 } & OR & $95 \%$ CI & $p$ \\
\hline Serum galectin-3 level (higher $v s$. lower) & 57.431 & $9.085-363.046$ & $<0.001$ \\
Sex (male $v s$. female) & 2.002 & $0.201-19.948$ & 0.554 \\
Smoking (smoker $v$ s. non-smoker) & 21.730 & $1.357-348.056$ & 0.030 \\
\hline
\end{tabular}

NSCLC: Non-small cell lung cancer; OR: Odds ratio; CI: Confidence interval; * $\mathrm{p}<0.05$.

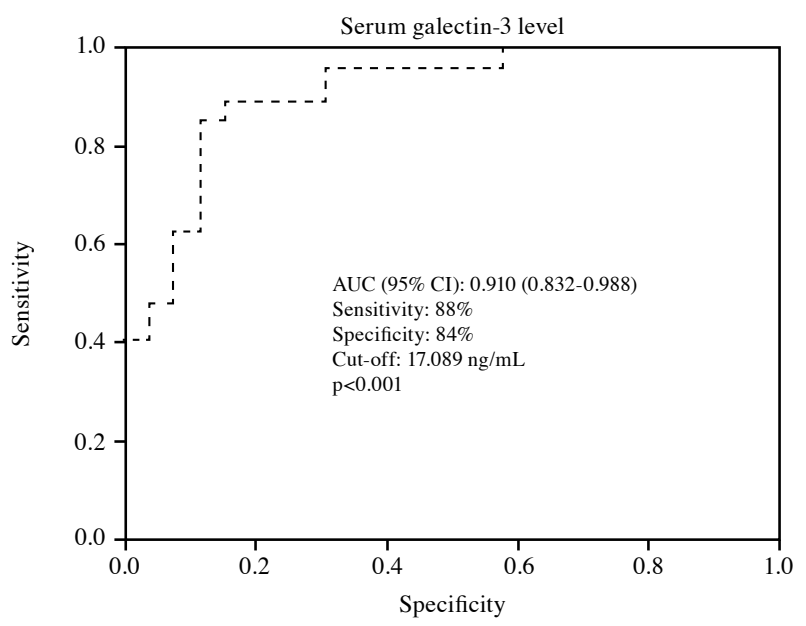

Figure 2. Receiver operating characteristics (ROC) analysis for serum galectin-3 level in NSCLC patients.

NSCLC: Non-small cell lung cancer. association of serum galectin-3 level, sex, and smoking status with NSCLC occurrence. It was shown that serum galectin-3 level (odds ratio [OR]: 57.431; 95\% confidence interval [CI]: 9.085-363.046; $\mathrm{p}=0.000)$ and smoking (OR: 21.730; 95\% CI: 1.357-348.056; $\mathrm{p}=0.03$ ) could be predictive risk factors of NSCLC influencing the diagnosis independent from variant distribution of galectin-3 (Table 6).

To further evaluate the diagnostic value of serum galectin-3 level in NSCLC patients, the ROC curve was plotted (Figure 2). The cut-off value of serum galectin-3 level was calculated as $17.089 \mathrm{ng} / \mathrm{mL}$ with the maximal sensitivity (88\%) and specificity (84\%) (AUC: $0.910 \pm 0.04$; 95\% CI: 0.832-0.988; p<0.001).

Galectin-3 mRNA expression level was determined in the tumor tissue, compared to the corresponding surrounding healthy tissue of the same participant for each NSCLC patient by the RT-qPCR. The mean galectin-3 mRNA expression was higher in surrounding healthy tissue referred to as control tissue $(0.09 \pm 0.039$ fold) $(0.09 \pm 0.039$ fold $)$ than tumor tissue $(0.04 \pm 0.012)$, although this difference was not statistically significant $(\mathrm{p}=0.4959)$ (Figure 3).

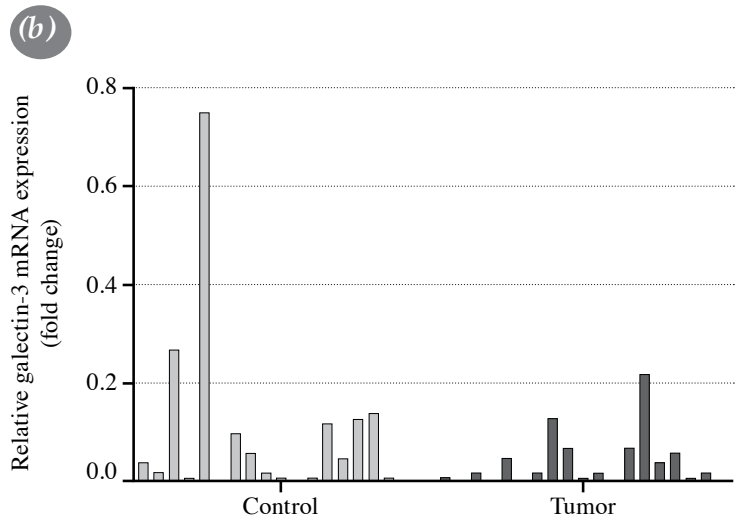

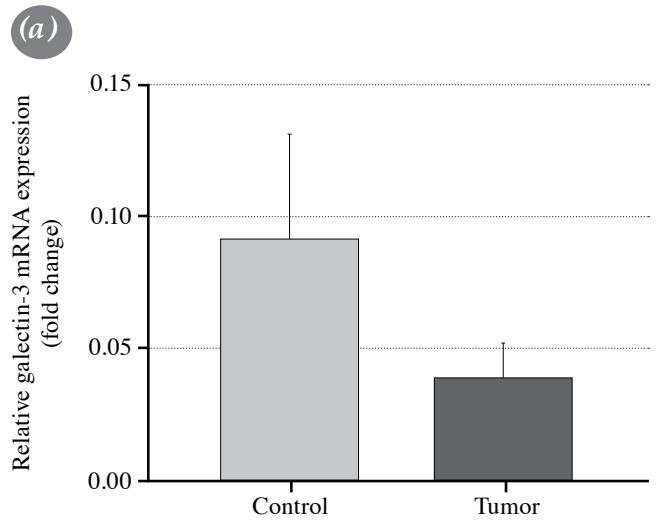

Figure 3. The comparison of galectin-3 mRNA expression levels (a) in control (surrounding healthy tissue) vs. tumor tissues of NSCLC patients ( $\mathrm{p}=0.4959)$ (b) individual distribution of galectin-3 mRNA expression level between control and tumor tissues.

NSCLC: Non-small cell lung cancer; mRNA: Messenger ribonucleic acid. 


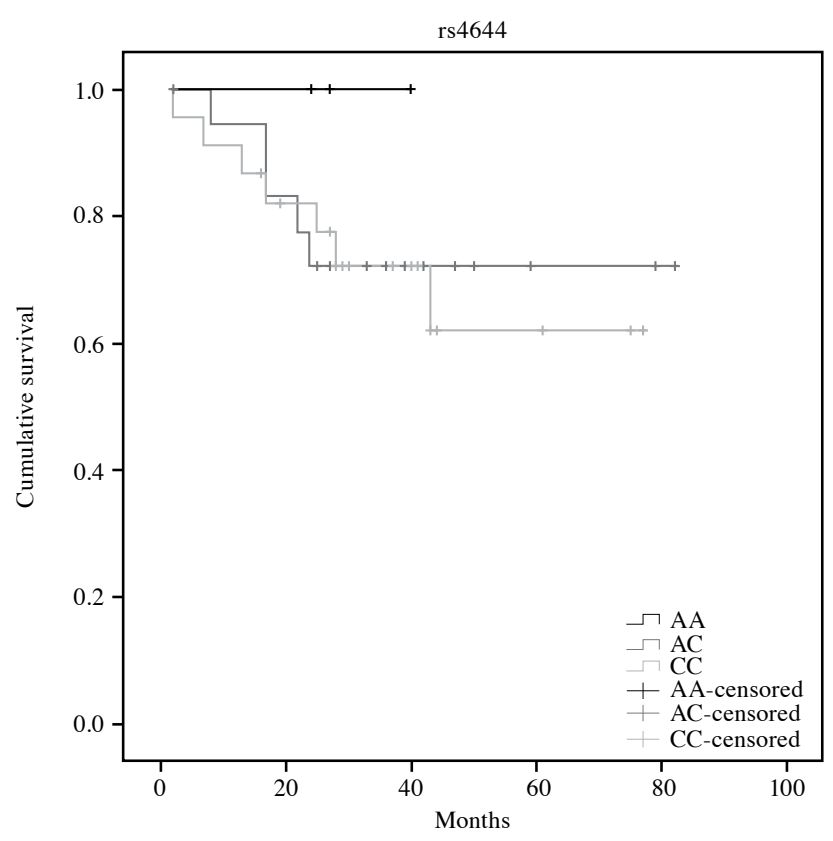

Figure 4. Survival of NSCLC patients according to genotypes with rs4644 variant of galectin-3. No statistically significant difference was found between groups $(\mathrm{p}=0.625)$.

NSCLC: Non-small cell lung cancer.

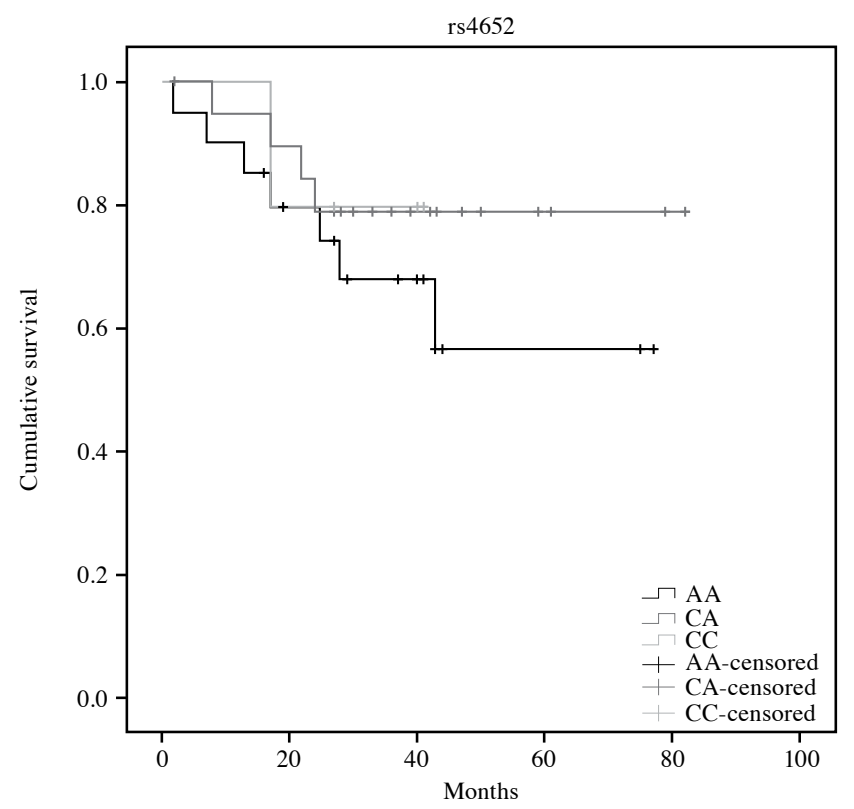

Figure 5. Survival of NSCLC patients according to genotypes with rs4652 variant of galectin-3. No statistically significant difference was found between groups $(\mathrm{p}=0.329)$.

NSCLC: Non-small cell lung cancer.

The five-year overall survival rate of operated NSCLC patients was $68.2 \%$ and the median survival time was 62.7 months (95\% CI: 53.4-72.1). While analyzing survival using log-rank comparison of survival data with regards to genotypes of galectin-3 gene variants, there was no statistically significantly different survival rates between the patients with genotypes of rs4644 variant $(\mathrm{p}=0.625)$ (Figure 4). Similarly, no statistically significant difference in the survival rates was found between patients with regards to rs4652 genotypes $(\mathrm{p}=0.349)$ (Figure 5). In terms of galectin-3 serum levels, the five-year survival rate of patients who had higher serum galectin-3 levels (>17.089 $\mathrm{ng} / \mathrm{mL}$ ) was $44.4 \%$, whereas it was $64.3 \%$ in the patients with lower serum galectin-3 levels $(\mathrm{p}=0.048)$ (Figure 6). The $\mathrm{N}$ factor, $\mathrm{T}$ factor, angiolymphatic involvement, and serum galectin-3 levels were subjected to the multivariate Cox proportional analysis. It revealed that only high levels of serum galectin-3 tended to be associated with survival of the patients (hazard ratio $[\mathrm{HR}]=5.106 ; 95 \%$ CI: 0.956-27.267; $\mathrm{p}=0.056$ ) (Table 7).

\section{DISCUSSION}

Many driver mutations and SNPs have been identified to elucidate the causative molecular mechanism underlying NSCLC. However, extensive clinical studies of lung cancer are still needed to use the genetic variations as a useful clinical diagnostic and prognostic marker. In our study, we examined the role of galectin-3 gene variants (rs4644 and rs4652) in tumor risk and survival of patients with surgically resected early-stage NSCLC. The patients and control groups were comparable in terms of sex and smoking status. However, males were found to have 4.9 times higher risk of having lung cancer consistent with the results of Kacan et al. ${ }^{[21]}$ Besides, smoking, particularly

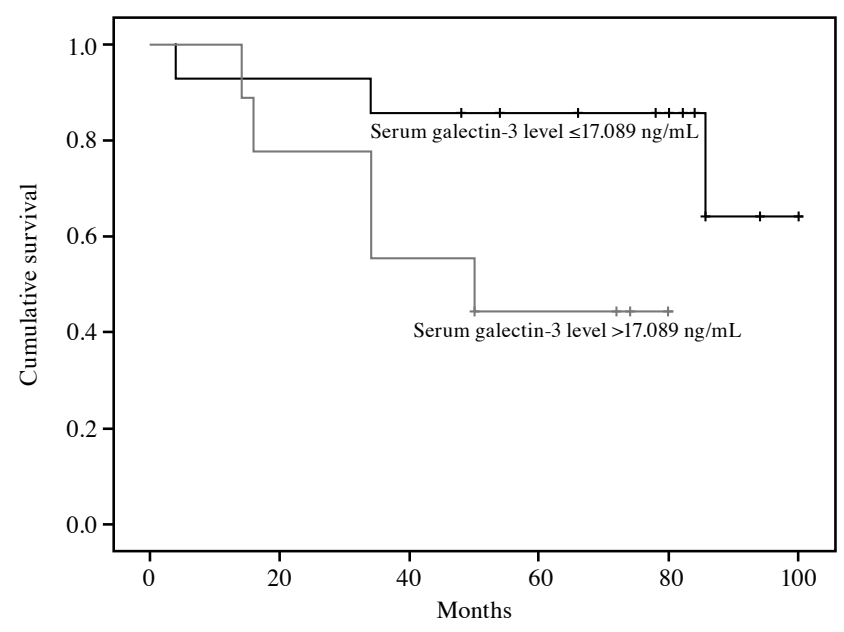

Figure 6. Survival of NSCLC patients according to serum galectin-3 levels. The difference was statistically significant $(\mathrm{p}=0.048)$.

NSCLC: Non-small cell lung cancer. 
Table 7. Multivariate cox regression model for death hazard estimation in NSCLC patients

\begin{tabular}{lccc}
\hline Parameters & Hazard ratio & $95 \%$ CI & $p$ \\
\hline Nodal metastasis (N1-2 vs. N0) & 2.45 & $0.471-12.79$ & 0.287 \\
T factor (T2-3 vs. T1) & 1.092 & $0.97-12.30$ & 0.943 \\
Lymphatic invasion (presence $v s$. absence) & 0.678 & $0.33-13.79$ & 0.800 \\
High serum galectin-3 level (>17.089 ng/mL) (higher $v s$. lower) & 5.106 & $0.956-13.79$ & 0.056 \\
\hline
\end{tabular}

NSCLC: Non-small cell lung cancer; CI: Confidence interval.

in parallel to male sex, is one of the most causes for lung cancer. In our study, $84.6 \%$ of the patients were smokers.

In terms of SNPs, the distribution of rs4644 and rs4652 variants were not found to be exclusive between the patients and controls. However, rs 4652 variant of galectin-3 was reported to be associated with platinumbased chemotherapy response and prognosis in patients with NSCLC rather than rs4644 variant. ${ }^{[22]}$ However, we did not analyze the response to chemotherapy of our patients, since all patients underwent resection surgery. Regarding the possible roles of rs4644 and rs4652 variants in the incidence of several cancer types, ${ }^{[13-17]}$ the sample size of the present study could be enlarged to reach statistical significance for the genotype and allele distribution between the patients and controls.

In our study, the frequency of patients with AA homozygous genotype of rs4652 variant was significantly increased in the presence of angiolymphatic invasion. In the studies including NSCLC patients with Stage I-IIA, having angiolymphatic invasion was found to be a negative prognostic factor for the development of long-term survival and relapse. ${ }^{[23]}$ However, we obtained no association between the genotypes of galectin-3 variants (rs4644 and rs4652) and survival in NSCLC patients.

Serum galectin-3 levels were higher in patients with $\mathrm{AC}$ and $\mathrm{CC}$ genotypes of rs4644 variant than in healthy controls. Moreover, rs4652 variant showed higher serum galectin-3 levels in patients with AA and AC genotypes, compared to the control group. There has been no study exemplifying the distribution of serum galectin-3 levels with respect to genotypes of galectin-3 variants in NSCLC patients. However, it has been evidenced that polymorphic amino acid changes in both the rs4644 and rs4652 positions along with the distribution of genotypes affect the secretion of serum galectin-3 in the body through taking an active role in various pathological processes which contribute to the cancer and other diseases. ${ }^{[12]}$ Nevertheless, the exact mechanism of how amino acid change alters the protein expression and function is still unclear. It is known that rs4644 in the $64^{\text {th }}$ residue which harbors proline than histidine has a more stable structure which is evolutionarily conserved, any change in this sequence is likely to affect the function of this molecule. ${ }^{[24]}$ Besides, proline amino acid at the $98^{\text {th }}$ residue of rs4652 variant is also known as critical in protein transportation. ${ }^{[22]}$ Studies on hamsters, $\mathrm{N}$-terminal sequence containing residues 89-96 (Tyr-Pro-Ser-Ala-Pro-Gly-Ala-Tyr) in the galectin-3 gene was found to play a critical role in protein secretion. ${ }^{[25]}$ Also, N-terminal region of galectin-3 is evolutionary conserved in mammalians. ${ }^{[22]}$ Therefore, human $\mathrm{N}$-terminal region located on the human rs 4652 variant of galectin-3, which is highly homologous to hamsters, may alter the intracellular galectin-3 level in the body.

Considering the pathological features of patients, in the presence of vascular invasion, serum galectin-3 levels were found to be higher in patients with AC genotypes of both rs4644 and rs4652 variants. The main molecular mechanisms proposed for the galectin-3 promoted angiogenesis include the binding of galectin-3 carbohydrate recognition domain (CRD) to $\alpha v 3$ integrins on endothelial cells, and subsequently inducing the signaling pathways related to angiogenic activity such as vascular endothelial growth factor, fibroblast growth factor, activation of focal adhesion kinase phosphorylation. ${ }^{[8]}$ Shi et al. ${ }^{[16]}$ hypothesized that an $\mathrm{A}>\mathrm{C}$ alteration at $\mathrm{rs} 4652$ site located on the CRD of galectin-3 might strengthen the interaction between CRD and fibroblast surface receptors, thereby, leading to pathway the myofibroblast promotion of angiogenesis and the growth of gastric cancer cells, ${ }^{[16]}$ as activated fibroblasts, also known as myofibroblasts, were thought to increase angiogenesis by interacting with cancer cells. ${ }^{[26]}$

Multivariate regression analyses have confirmed that smoking contributed to the lung cancer risk matching variables such as age and sex. ${ }^{[27]}$ To extend 
the work of literature, serum galectin-3 level was also identified as a promising predictive risk factor for NSCLC in our study. Furthermore, the cut-off value of serum galectin-3 level $(17.089 \mathrm{ng} / \mathrm{mL})$ was proposed for assessing the discriminatory accuracy between NSCLC patients and healthy individuals.

Finally, in the survival analysis, we found that rs4644 and rs4652 genotypes of galectin-3 were not associated with survival. However, we found that high serum galectin-3 level was marginally associated with lower survival among NSCLC patients. Multivariate analysis indicated that high serum galectin-3 level tended to be an independent surrogate marker for worse survival. This finding may help to select patients for possible adjuvant, despite having earlystage tumors. It is also plausible to propose that the patients with higher serum galectin-3 levels could be followed more frequently for possible earlier recurrences. Similarly, Kataoka et al. ${ }^{[28]}$ found that higher expressions of galectin-3 in tumor cells were associated with tumor recurrence. However, they did not perform multivariate analysis to prove that whether high galectin-3 level was independently related with worse survival.

The main limitations to our study include relatively low number of patients and the matching problems for sample from the same study population, resulting from the exclusion of certain patients, particularly for the expression analysis. Therefore, a heterogeneous gene expression profile of galectin-3 was obtained among tumor tissues of NSCLC patients. A larger series with the analysis of higher number of patients could have revealed a statistically significant association between serum galectin-3 level and survival. Thus, the outcomes of this study warrant further confirmation with larger groups.

In conclusion, the present study may provide a basis for the literature investigating the role of galectin-3 variants in lung cancer by shedding light into whether galectin-3 may be one of the important biomarkers to be suggested in disease risk and progression. Serum galectin-3 level may be utilized to better identify patients with early-stage lung cancer who can benefit from adjuvant therapy after surgical resection. Further in vitro studies are needed to elucidate cellular functional changes in cancer signaling pathways related to rs4644 and rs4652 variants of galectin-3.

\section{Declaration of conflicting interests}

The authors declared no conflicts of interest with respect to the authorship and/or publication of this article.

\section{Funding}

This study was supported by the grant from Istanbul University Scientific Research Found (IU BAP; TDK-201827977).

\section{REFERENCES}

1. Siegel RL, Miller KD, Jemal A. Cancer statistics, 2019. CA Cancer J Clin 2019;69:7-34.

2. Goldstraw P, Crowley J, Chansky K, Giroux DJ, Groome PA, Rami-Porta R, et al. The IASLC Lung Cancer Staging Project: Proposals for the revision of the TNM stage groupings in the forthcoming (seventh) edition of the TNM classification of malignant tumours. J Thorac Oncol 2007;2:706-14.

3. Liao Z, Lin SH, Cox JD. Status of particle therapy for lung cancer. Acta Oncol 2011;50:745-56.

4. Detterbeck FC, Boffa DJ, Tanoue LT. The new lung cancer staging system. Chest 2009;136:260-71.

5. Chang A. Chemotherapy, chemoresistance and the changing treatment landscape for NSCLC. Lung Cancer 2011;71:3-10.

6. Kadrofske MM, Openo KP, Wang JL. The human LGALS3 (galectin-3) gene: Determination of the gene structure and functional characterization of the promoter. Arch Biochem Biophys 1998;349:7-20.

7. Liu FT, Rabinovich GA. Galectins as modulators of tumour progression. Nat Rev Cancer 2005;5:29-41.

8. Markowska AI, Liu FT, Panjwani N. Galectin-3 is an important mediator of VEGF- and bFGF-mediated angiogenic response. J Exp Med 2010;207:1981-93.

9. Takenaka Y, Fukumori T, Raz A. Galectin-3 and metastasis. Glycoconj J 2002;19:543-9.

10. Saussez S, Lorfevre F, Lequeux T, Laurent G, Chantrain $\mathrm{G}$, Vertongen $\mathrm{F}$, et al. The determination of the levels of circulating galectin-1 and -3 in HNSCC patients could be used to monitor tumor progression and/or responses to therapy. Oral Oncol 2008;44:86-93.

11. Chung LY, Tang SJ, Wu YC, Sun GH, Liu HY, Sun KH. Galectin-3 augments tumor initiating property and tumorigenicity of lung cancer through interaction with $\beta$-catenin. Oncotarget 2015;6:4936-52.

12. Hu CY, Chang SK, Wu CS, Tsai WI, Hsu PN. Galectin-3 gene (LGALS3) +292C allele is a genetic predisposition factor for rheumatoid arthritis in Taiwan. Clin Rheumatol 2011;30:1227-33.

13. Balan V, Nangia-Makker P, Schwartz AG, Jung YS, Tait $\mathrm{L}$, Hogan V, et al. Racial disparity in breast cancer and functional germ line mutation in galectin-3 (rs4644): A pilot study. Cancer Res 2008;68:10045-50.

14. Meyer A, Coinac I, Bogdanova N, Dubrowinskaja N, Turmanov N, Haubold S, et al. Apoptosis gene polymorphisms and risk of prostate cancer: A hospital-based study of German patients treated with brachytherapy. Urol Oncol 2013;31:74-81.

15. Chen HJ, Zheng ZC, Yuan BQ, Liu Z, Jing J, Wang SS. The effect of galectin-3 genetic variants on the susceptibility and prognosis of gliomas in a Chinese population. Neurosci Lett 2012;518:1-4. 
16. Shi Y, Lin X, Chen G, Yan J, Ying M, Zheng X. Galectin-3 rs4652 $\mathrm{A}>\mathrm{C}$ polymorphism is associated with the risk of gastric carcinoma and P-glycoprotein expression level. Oncol Lett 2017;14:8144-9.

17. Fang SQ, Feng YM, Li M. Correlations of galectin-3 gene polymorphisms with risk and prognosis of cervical cancer in Chinese populations: A case-control study. Oncol Res Treat 2017;40:533-9.

18. Groome PA, Bolejack V, Crowley JJ, Kennedy C, Krasnik M, Sobin LH, et al. The IASLC Lung Cancer Staging Project: validation of the proposals for revision of the $\mathrm{T}, \mathrm{N}$, and $\mathrm{M}$ descriptors and consequent stage groupings in the forthcoming (seventh) edition of the TNM classification of malignant tumours. J Thorac Oncol 2007;2:694-705.

19. Miller SA, Dykes DD, Polesky HF. A simple salting out procedure for extracting DNA from human nucleated cells. Nucleic Acids Res 1988;16:1215.

20. Akobeng AK. Understanding diagnostic tests 3: Receiver operating characteristic curves. Acta Paediatr 2007;96:644-7.

21. Kacan M, Turkyilmaz M, Karabulut F, Altun O, Baran Y. Complexation, thermal and catalytic studies of N-substituted piperazine, morpholine and thiomorpholine with some metal ions. Spectrochim Acta A Mol Biomol Spectrosc 2014;118:572-7.
22. Wu F, Hu N, Li Y, Bian B, Xu G, Zheng Y. Galectin-3 genetic variants are associated with platinum-based chemotherapy response and prognosis in patients with NSCLC. Cell Oncol (Dordr) 2012;35:175-80.

23. Sung SY, Kwak YK, Lee SW, Jo IY, Park JK, Kim KS, et al. Lymphovascular invasion increases the risk of nodal and distant recurrence in node-negative stage I-IIA non-smallcell lung cancer. Oncology 2018;95:156-62.

24. Kaur T, Sodhi A, Singh J, Arora S, Kamboj SS, Kaur M. Evaluation of galectin-3 genetic variants and its serum levels in rheumatoid arthritis in North India. International Journal of Human Genetics 2015;15:131-8.

25. Menon RP, Hughes RC. Determinants in the N-terminal domains of galectin-3 for secretion by a novel pathway circumventing the endoplasmic reticulum-Golgi complex. Eur J Biochem 1999;264:569-76.

26. Webber JP, Spary LK, Sanders AJ, Chowdhury R, Jiang WG, Steadman R, et al. Differentiation of tumour-promoting stromal myofibroblasts by cancer exosomes. Oncogene 2015;34:290-302.

27. Bach PB, Kattan MW, Thornquist MD, Kris MG, Tate RC, Barnett MJ, et al. Variations in lung cancer risk among smokers. J Natl Cancer Inst 2003;95:470-8.

28. Kataoka Y, Igarashi T, Ohshio Y, Fujita T, Hanaoka J. Predictive importance of galectin-3 for recurrence of non-small cell lung cancer. Gen Thorac Cardiovasc Surg 2019;67:704-11. 